\title{
Corporate Governance and Financial Performance of Bank in Asian Regions and Recommendations
}

\author{
Ping-fu LAI (Brian) (Corresponding Author) \\ Division of Business and Management \\ United International College \\ Beijing Normal University Hong Kong Baptist University \\ PO Box 74107, Kowloon Central Post Office, Hong Kong \\ E-mail: blai8733@gmail.com \\ On-na CHOI (Anna) \\ ABRS International Consultancy \\ PO Box 74107, Kowloon Central Post Office, Hong Kong
}

Received: Oct. 8, 2014 Accepted: Nov. 17, $2014 \quad$ Published: December 1, 2014

doi:10.5296/ajfa.v6i2.6429 URL: http://dx.doi.org/10.5296/ajfa.v6i2.6429

\begin{abstract}
This research analyzes the bank's corporate governance with financial performance relationship in Asian regions. As we know, corporate governance helps to promote prosperity, financial performance and economic growth. In this research, we use multiple linear regression analysis and correlation matrix to explain the effect of explanatory variable; namely, Capital $(C A R)$, Profitability (PTC and ROAA), Asset Size (TA) and Asset Quality $(N P L)$ on a proxy variable which are the Corporate Governance $(C G)$, Board Size $(B S)$ and Board Meeting $(B M)$. Findings are that there is statistically significant relationship between $C A R, P T C$ and corporate governance. TA, NPL, ROAA are not statistically significant relationship between corporate governance. There is also statistically significant relationship between CAR, PTC and board size. TA, NPL and ROAA are not statistically significant relationship between board sizes. Besides, there is showed statistically significant relationship between PTC, TA, ROAA and board meeting. CAR and NPL are not statistically significant relationship between board meetings. Additionally, this study also finds that financial performance of banks in Year 2007-2008 (financial crisis) is statistically different from that of Year 2011-2012. Since banks faced slowdown in the US economy and financial crisis in Year
\end{abstract}




\section{Macrothink}

Asian Journal of Finance \& Accounting ISSN 1946-052X 2014, Vol. 6, No. 2

2007-2008. It shows that PTC and ROAA are no statistically significant difference. $C A R, T A$ and $N P L$ are statistically significant difference. The methods of banks use to improve corporate governance and financial performance via strengthen internal control and ensure compliance is important. It can help management to respond risk quickly and achievement of objectives.

Keywords: Corporate Governance, Board Sizes, Board Meetings, Asian Region's Banks, Financial Performance

JEL Classification: J11, J16 


\section{Introduction}

The nature of the banking business is such that the creditworthiness of banking institutions are often observed to be closely linked to the economic environment in which it operations and the systematic risk of a failure in the banking sector. According to the bank's annual report, we can realize the bank risk management and corporate governance. Risk management and corporate governance is the key factors to effect bank operation. Good corporate governance indicated the board of directors and others senior management should have clear understanding about of the risks and what risk is the bank facing. There should have complete monitoring and management reporting system for the bank's business complexity and diversity. The management should have good expertise and experience to receive timely information; they have duty to monitor bank performance. Board of directors has an agency relationship with the stakeholders. They should take the responsibility to maintain shareholder's interest, good long-term financial and operation performance. The benefits of applying good corporate governance can help to stimulates performance. Bank should be institutes clear accountability and effective links between performance and rewards, which can encourage the employees to improve its performance. And it also can reduce the level of risk as perceived by investors, protecting shareholder's rights; it can maintain a good profit (Andres and Vallelado 2008). The aim of this study is to find out the financial condition of credit risk ratio which is more important to represent bank's performance; we can know the importance of corporate governance.

\section{Literature Reviews}

\subsection{Theoretical Background}

Corporate governance as a system, that organizations are directed and controlled. It provided a framework for pursuing and achieving organization's goal and monitoring performance and reduces risk. Management goal is maintaining the interests of the organization and its shareholders. Moreover, it should be monitor effectively and encourage enterprises to use the resources correctly (Cadbury Report 1991). If the organizaton wants to avoid conflict of interest that it should be appointment of independent non-executive directors. Based on agency perspective, it should be separation of the roles of CEO from chairman (William et al. 2003). Corporate governance emphasised the directors should be accountability to the stakeholders (Novikova, 2004).

Good corporate governance should be promoted corporate or bank's true and fair view, transparency and accountability. It cannot have any conflict of interest. Board of directors is the most important device to monitor the management and the independency of board members (Abdullah, 2004). It needs take the responsibility to accountable to the stakeholders. It can help to built up positive management image. Corporate governance mechanisms assure investors in corporation that they will receive adequate returns on their investments (Shleifer and Vishny, 1997).

According to various studies, we found that there was existed many factors would effects financial performance. V. H. Vroom (1964) suggested that people consciously choose 
particular courses of action, based upon perceptions, attitudes, and beliefs, as a consequence of their desires to enhance pleasure and avoid pain. Motivation was a key component of leadership; the leaders could create motivating environments for their followers. The incentives promoted effort and performance, and there was a lot of evidence that they often do (Gibbons 1997 and Lazear, 2000). Contingent rewards serve as "positive rein forcers" for the desired behavior. Good corporate governance could help to promote bank's goodwill and image. It could help to motivate people have creative thinking in different aspects. Recent studies researches showed that good corporate governance could help to increase valuation, high profit, sales growth and low expenditure (Wolfgang, 2003). The remuneration was associated with the incentive alignment which depends on the strength of corporate governance (Sun, Jerry \& Cahan, Steven F. \& Emanuel, David (2009).). Corporate governance quality would affect executive's compensation and bank performance, if bank could improve the corporation governance quality that it could help to increase bank performance and reduce agency problems. But it was also needed possess strong management's leadership to promote success corporate governance. Leadership style had been became an issue and topic which decided the competence. Leader's age, year of experience, educational level and genders was always taken into consideration (Bass, 1990). It showed good corporate governance could help to increase expertise and strategic decision making. All board members were encouraged to examine board decisions critically.

Principal agent relationship in corporate governance was the necessary in theoretical. Managers had responsibility to maximum shareholders interests but could not have any conflict of interest. Due to ownership and control was separation, there was the relationship between the shareholders and management. Agency theory was indicated agents might care their own interest then would ignore the interest of principal, so shareholders would take action to restrict their behavior, so it caused agency conflict. Core et al. (2001) and Murphy (1999) suggested that the sensitivity of executive compensation to firm performance had increased over times. Board should be determined the company's direction and performance of interaction. Internal corporate governance factors could effective interaction among a company's management, board and shareholders. It should be regular report the management situation to the boards and others stakeholders. It was argued that the executive compensation was the "smoking gun" of governance failure (Monks, 2005). The executive pay might be the substitute of the outside directors (Coulton and Taylor, 2004). Executive compensation in the form of 'optimal contracting approach' might play a key role in resolving the agency problem in areas where the monitoring was difficult (Mangel, 1993).

Good corporate governance had become more important because practice needed achieve transparency and accountability requirements. Banks listed in capital markets was tended to have better corporate governance practices because they were closely monitored by investors who demand that the banks should increase their transparency and disclosure (Akhigbe and Martin, 2008). Corporate governance could help to improve company performance. The empirical researches found that corporate governance practices could have a positive impact on bank performance (Gompers et al., 2003; Brown and Caylor, 2006; Andres and Vallelado, 2008; Bhagat and Bolton, 2008). It was most common that researchers used company age, 
audit firm, auditor's quality, auditor and client relationship to do testing.

Corporate governance indicated increases the importance of the financial information's transparency and monitor on the corporate reporting. Since auditing quality arouse the public attention. The institutional environment had a significant impact on the functioning of corporate governance (Cuervo, Reese and Weisbach, 2002). It was brought the characteristics of the governance and audit market. Simunic's (1980) described audit pricing model considers client characteristics such as size, complexity, profitability and client-specific risk. The variables had a significant impact on audit fees. Francis and Wilson (1998) and Defond (1992) showed that the degree to which audit clients was confronted with agency conflicts influence their choice of audit quality. The articles also indicated the negative effect of audit committee on bank performance could be attributed to the audit committee members' lack of expertise in helping the board in the governance of the bank.

It seemed that the wider pool of knowledge and experience available to the board could help the board to identify opportunities more readily. A larger board of directors was beneficial and would increase the collection of expertise and resources accessible to a firm (Dalton, Daily, Johnson, \& Ellstrand, 1999). But, Jensen (1993) argued that board size increase, the efficiency of the boards would decrease due to increase in decision-making time. Board size too large sometimes was not good, because it might lack of time monitor. Yermack (1996) reported that a larger board was comprised of experts from various fields; however, an excessively large board would drag down the efficiency of the board and also the effectiveness of corporate governance mechanisms. The size of the boards was the important governance consideration. Since many studies indicated board independency, CEO duality and board size was more relevant to corporate governance if the boards could success to discharge their fiduciary duties that it would be increased company value and shareholder wealth (Abdullah, 2004). Some researches indicated a negative relationship between board size and company performance (Yermack, 1996).

Directors followed the accounting policies could make them possess better risk alert in the environment and raised the ability of evaluation. The assessment prepared by management should be contained a wide range analysis which was related to company's profitability, collect debt and financing aspects. During credit crunch, risk should be needed to identify, classify, assessment and tackling. Management had duty to evaluate the impacts and probability of happening and found ways to solve. The company might face different types of risks or difficulties in operation. Therefore, management should be helped the company set policy and objective to safeguard company and respond risk. Corporate governance had many testing factors such as Leverage; and Dividend used to test a positive or a negative influence on company's performance. Crutchley and Hansen (1989) showed the evidence of dividend policy acting as a corporate monitoring vehicle. Board Committees was also took into consider elements, Klein (1998) found that it had evidence of a positive relationship between the presence of a RCOM and firm financial performance. Use ROE as a proxy of bank performance relevant to shareholder's investment (Siamat, 2004; Berger, et al., 2005; Kim and Rasiah, 2010). Lin and Zhang (2009) deployed return on equity (ROE) as an alternative measure of profitability. To solve the relationship between corporate governance and bank 
performance, Capital adequacy ratio was an important element to affect bank financial performance. Through in-depth review of the literatures, we explored the effects of financial performance of bank had the several main variables. It seen that dividend yield was a comparable valuable to reflect whether company had ability to satisfy shareholder's interest. Since higher dividend yield had been considered desirable by many investors.

Many studies about bank performance were focused on branch performance in South Africa (Oberholzer and Vander Westhuizen, 2004). The measurement of bank performance in commercial banks had increased attention over the past years (Seiford and Zhu, 1999). Size would be affected on the financial variables accord several literature (Samad, 2004). It was common used financial ratios to measure organization's performance. Bank regulators measure banks which were mainly accorded bank's liquidity, solvency or overall performance to consider their ability. Measure bank performance could enhance managerial ability in setting good corporate governance practices; it could help to improve bank efficiency. Traditionally accounting methods was based on the financial ratios for assessing bank performance (Ncube, 2009). Pi and Timme (1991) showed that it had significantly positive between efficiency and the ratio of loans to total assets. Meinster and Elyasiani (1988) indicated that several financial ratios were selected to assess the financial performance to asset management ratios, expense and profitability and risk management ratios.

Oberholzer and Van Der Westhuizen (2004) found the efficiency and profitability of banking in South Africa, the results was an efficiency measure existed relationship between profitability and efficiency ratios. Financial ratios could be used to identify a bank's specific strengths and weaknesses as well as providing detailed information about bank profitability, liquidity and credit quality policies (Hempel et al, 1994; Dietrich, 1996). It indicated evaluate banks past performance which could help to plan for bank's future performance (Hempel et al, 1994). It was common to use ratios to measure the financial performance and compare with the past to make interpretations (Oberholzer and Westhuizen, 2004). The operating efficiency had an affect on the bank size. Pilloff and Rhoades (2002) said a positive relationship existed between the profitability and bank size.

Although financial statements were backward looking, they were only detailed information available on the bank's overall activities (Sinkey, 2002). It could provide information to evaluate company future whether it had ability to get reasonable returns. Samad (2004) indicated that liquidity was the life and blood of a commercial bank. The objective of the banks was to reduce the bad loans and lending losses. Due to outbreak of before global economic crisis, so it might be common to found research about the financial performance indicators of bank (Casu et al, 2006). Al-Tamimi (2012) examined the relationship between corporate governance practices of UAE national banks and performance level. Hassan and Al-Mazrooei (2007) stated the UAE risk management practices and techniques of the bank.

Dietrich and Wanzenried (2011) showed that the global financial crisis was affected the profitability of Swiss commercial banks during the crisis years 2007-2009. Cornett, M (2009) showed the banks during the financial crisis with more illiquid asset portfolios, banks would be increased liquid assets and decreased lending. Bank's financial performance would affect 
by economic crisis. So, good corporate governance could help to improve problems. Sufian (2009); Molyneux and Seth (1998); Ramlall (2009) also found an affirmative relation of bank size and examined the dependence of bank size upon economies of scale because smaller banks were less profitable than larger banks. Whereas Koasmidou (2008); Spathis, Koasmidou \& Doumpos (2002) found empirically a negative relation existed between bank size and profitability.

Bank size and financial ratios such as efficiency / profitability ratios, liquidity ratios, capital/ leverage ratios and asset quality ratios was effective tool to classify the public and private banks and these ratios was also suggested by SBP statistical bulletin to evaluate the financial performance of banks. Financial measures such as return on assets (ROA), interest margins (IM) and capital adequacy (CA) had positive relation with customer service quality (Elizabeth \& Elliot, 2004). Raza, Farhan \& Akram (2011) classified the investment banks in his study using return on total assets (ROA) and return on owners' equity (ROE). Effectiveness and efficiency was the independent factors (Tarawneh, 2006). There was no boundness that efficient bank also had effectiveness always.

Ahmad Almazari (2011) studied the financial performance of seven Jordanian commercial banks. He used the ROA to measure. The results of his analysis reflected a strong negative correlation between ROA and bank's size, a strong positive correlation between ROA and asset management ratio, and a negative weak correlation between ROA and operational efficiency. Khizer Ali, Muhammad Akhtar and Hafiz Ahmed (2011) conducted a comprehensive study about banks' profitability in Pakistan, where they found significant relation between asset management ratio, capital and economic growth and with ROA. While they found that operating efficiency, asset management and economic growth was significant with the ROE.

It was common that researchers were mostly to use Return of Equity (ROE), Return of Assets (ROA) and Earning per share (EPS) to test the relationship between board characteristics (Grossman, 2000). Muhammad Sidqui and Adnan Shoaib (2011) found their study "Measuring performance through capital structure in Pakistan" that size of the bank played a significant role in determining the profitability of the bank measured by ROE. They used also the Tobin's Q model as a proxy of determining banks performance while they found that Tobin's Q was affected by the size of the bank, the leverage ratio and Investments carried out by the bank. Greenidge and Grosvenor (2010) argued that the non-performing loans were an important element in the financial and banking crises. Guy (2011) said that non performing loans had been widely used as a measure of asset quality among financial institutions. Morrison and White (2001) pointed out that the capital adequacy ratio requirement was useful to limit the size of the group; it could avoid moral hazard problems.

\section{Research Methodology}

\subsection{The importance of this study of the following points}

Dependent variable of corporate governance, board size and board meeting can use to test the relationship between other independent variables (Capital, Asset Size, Profitability and Asset 
Quality) to represent financial condition. Financial condition ratio is absolutely can show that bank's risk management does best or not. Bank has ability to reduce non-performing loans and earn great profit. Financial performance is absolutely can reflect on EPS. EPS increase or decrease that is absolutely represents bank profitability performance. We want to know credit risk performance do better or worst whether its can really reflect in EPS. This study wants to using variables to indicate the significant indicators of the relationship between corporate governance and financial condition (credit risk). Risk management needs how to reduce risk to achieve corporate governance requirements. It also gives suggestions about how to improve bank financial performance.

\subsection{Data Collection}

In this analysis, the data were collected from different bank in Asian regions such as Hong Kong and China. We would search for updated annual report of each bank. The annual reports information of bank must be available for the period from Year 2007-2012. The calculation could be accorded each bank's annual report to calculate the value or percentage. The information could be searched from www.pwc.com, http://finance.yahoo.com/ or others finance websites.

\section{Data Finding and Analysis}

(a)

Firstly, this study also wants to examine whether the financial performance of the banks in Year 2007-2008 is statistically different from that of Year 2011-2012. So, it will be used t-test to test the hypothesis that the means of the two periods are the same on the five variables. The following hypothesis is set $\mathrm{H}_{0}: \mu_{1}=\mu_{2}$, where $\mu_{1}$ is the mean for Year 20072008 and $\mu_{1}$ is the mean for Year 2011-2012. The hypothesis is decided by looking at $t$ test statistics and critical values associated with the mean.

Table 1.

\begin{tabular}{|c|c|c|c|c|}
\hline Capital & $C A R$ & \begin{tabular}{|l} 
Mean \\
Year 2007-2008 \\
0.147
\end{tabular} & $\mid \begin{array}{l}\text { Mean } \\
\text { Year 2011-2012 } \\
0.130\end{array}$ & $\begin{array}{l}\text { P- value } \\
0.002\end{array}$ \\
\hline Asset Size & TA & 354441.120 & 237817.900 & 0.019 \\
\hline Asset Quality & NPL & 0.007 & 0.015 & $3.05619 E-06$ \\
\hline \multirow[t]{2}{*}{ Profitability } & PTC & 0.240 & 0.233 & 0.660 \\
\hline & ROAA & 0.014 & 0.039 & 0.315 \\
\hline
\end{tabular}

With regard to capital, CAR showed banks performed better in the year 2007-2008 compared to Year 2011-2012. According to the above table, the mean of CAR is 0.147 in Year 2007-2008 which is compared to 0.130 in Year 2011-2012. The p-value is 0.002 , so the difference between the performances for two periods is statistically significant because the p-value is smaller than the significant level of $5 \%$, therefore the null hypothesis can be rejected. About the profitability, $P T C$ and ROAA showed banks performed better in the year 


\section{Macrothink}

Asian Journal of Finance \& Accounting

ISSN 1946-052X

2014, Vol. 6, No. 2

2007-2008 compared to Year 2011-2012. According to the above table, the mean of PTC is 0.240 in Year 2007-2008 which is compared to 0.233 in Year 2011-2012. The mean of ROAA is 0.014 which is compared to 0.039 in Year 2011-2012. The p-value of PTC and ROAA are 0.660 and 0.315 respectively, so the difference between the performances for two periods is not statistically significant because the p-value is greater than the significant level of $5 \%$, therefore the null hypothesis cannot be rejected.

With reference to asset size, TA shows banks performed better in the year 2007-2008 compared to Year 2011-2012. The p-value of $T A$ is 0.019 , so the difference between the performances for two periods is statistically significant because the p-value is smaller than the significant level of 5\%, therefore the null hypothesis can be rejected. Besides, NPL showed banks perform worst in the year 2007-2008 compared to Year 2011-2012. The mean of NPL is 0.007 in Year 2007-2008 which is compared to 0.015 in Year 2011-2012. The p-value of $N P L$ is $3.05619 E-06$, so the difference between the performances for two periods is statistically significant because the p-value is smaller than the significant level of 5\%, therefore the null hypothesis can be rejected. To conclusion the above results, PTC and $R O A A$ are no statistically significant difference. $C A R, T A$ and $N P L$ are statistically significant difference.

(b)

Table 2.

Anova: Single Factor

SUMMARY

\begin{tabular}{|c|c|c|c|}
\hline Groups & Count & Sum & Average Variance \\
\hline Board Size (BS) & 180 & 2620 & 14.5555610 .38237 \\
\hline $\begin{array}{l}\text { Board Meeting } \\
(B M)\end{array}$ & 180 & 1266 & 7.03333311 .88715 \\
\hline
\end{tabular}

ANOVA

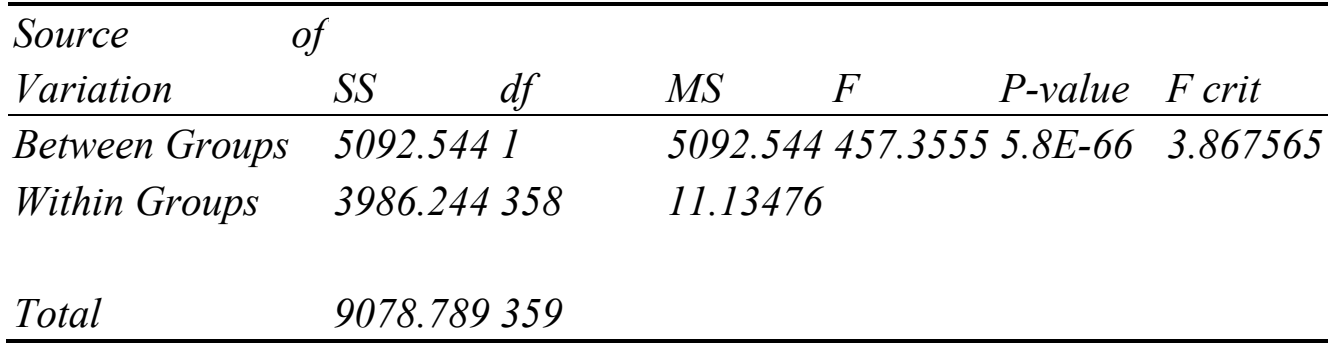




\section{Mll Macrothink}

Table 3.

t-Test: Two-Sample Assuming Equal Variances

\begin{tabular}{lll}
\hline & $\begin{array}{c}\text { Board } \\
(B S)\end{array}$ & $\begin{array}{c}\text { Size Board } \\
(\text { BM })\end{array}$ \\
\hline Mean & 14.55556 & 7.033333 \\
Variance & 10.38237 & 11.88715 \\
Observations & 180 & 180 \\
Pooled Variance & 11.13476 & \\
Hypothesized & Mean & \\
Difference & 0 & \\
df & 358 & \\
$t$ Stat & 21.38587 & \\
$P(T<=t)$ one-tail & $2.9 E-66$ & \\
$t$ Critical one-tail & 1.649121 & \\
$P(T<=t)$ two-tail & $5.8 E-66$ & \\
$t$ Critical two-tail & 1.966613 & \\
\hline
\end{tabular}

To test whether the average size of board meeting frequency $(B M)$ and board size $(B S)$ was existed a significant difference. With reference to the Group, according to ANOVA, F-test statistic is 457.3555 with p-value of $5.8 E-66$. Since the p-value is less than 0.05 , we reject the null hypothesis that regression parameters are not zero at significance level 0.05 . F value is greater than 2.2660. It concluded that the parameters are jointly statistically significant at significance level 0.05 . The $t$ static value is 21.386 larger than 2.179 and p-value smaller than the level of significance $5 \%$. Thus, the null hypothesis is rejected. There is existed statistically significant relationship. According to the two-sample assuming equal variances, the pooled variance is 11.135 , the t static 21.386 and p-value of two-tail is $5.8 \mathrm{E}-66$.

(c)

After the review of literatures and methodology, it is decided to find the correlation of the several factors with financial performance indicators to the banks, to see those banks financial performance under corporate governance practices, guideline influence and board size and board meeting 1) Capital Adequacy Ratio (Capital), 2) Total Assets (Asset Size), 3) Profit before tax to tier 1 capital (Profitability), 4) Non-performing loans to total assets (Asset Quality) and 5) Return on average assets (Profitability). The study consists of independent variables the Bank's financial condition with ratio analysis (capital, asset Size, profitability, asset quality) also dependent variable (corporate governance), (board size) and (board meeting).

The Qualitative assessment of bank's operations on $C G$ :

Part 1 
(a) The dependent variable of Corporate Governance $(C G)$

Risk management and corporate governance aspects, competent risk management and corporate governance are essential to bank's operation. The important indicators of good risk management structure and corporate governance are:

Board of directors and senior management should have a clear understanding about bank's risk is facing.

There are comprehensive policies and identification of measurement, control and monitoring procedures for each type of risk.

There are an efficient built up monitoring and management reporting system that it can have ability to cope with the complexity and different bank's operations.

Board of directors and senior management possesses with good professional knowledge and experience. They have ability to get update information and monitoring management performance.

Part 2

(b) The dependent variable of board sizes $(B S)$

The meaning of the board size is calculated the number of directors on the boards.

Part 3

(c) The frequencies of board of directors meetings $(B M)$

The frequencies of board of directors meetings may be seem as an important factor in board effectiveness. Godard et al (2004) indicated that increase the number of board meetings has a positive influence on the finance performance of French companies.

The Quantitative assessment of bank's financial condition or performance:

- A bank's financial position, its credibility objective indicators is the strongest. It should consider four key aspects in the evaluation of a bank's financial position, which is a major factor affecting performance such as the bank's capital, asset size, profitability and asset quality. All data can find in the annual report such as balance sheet and income statement.

$\diamond \quad$ Capital $(\mathrm{C})$

The assessment of capital can be dividend into two types; one is capital adequacy and soundness of assets ratio. In this study, capital adequacy ratio will be took into consider used as capital parameters.

$\diamond \quad$ Capital adequacy ratio $(\%)(C A R)$

Capital adequacy ratio reflects the bank's ability to absorb unexpected losses. Capital adequacy is measured by capital adequacy ratio, which is based on the bank's risk-weighted assets. Banks should at least meet the minimum regulatory capital requirements. Currently, the Basel Committee proposed minimum capital adequacy ratio of $8 \%$. 
$\diamond \quad$ Soundness of assets ratio

Tier 1 capital / assets (\%)

Tier 1 amount used as indicator of the capital quality. Tier 1 capital as indication of the capital quality. If the ratio is higher, bank can have better quality and reduce the risk of bank.

Tier 1 capital is means the core capital of the bank, it is calculated accord to Basel Capital accord and it included share and retained earnings normally.

$\diamond \quad$ Asset Size (AS) (\$)

Total Assets $(T A)$

It is very easy for their business or a diversified portfolio of large banks, so they are less vulnerable to specific shocks. Asset size is also related to the "market position", which is commonly used in the quantitative analysis of long-term credit. If a bank's command significant market shares, it will also have significant pricing power, a broader capital base and better quality of service.

$\diamond \quad$ Profitability $(\mathrm{P})(\%)$

(1) Profit before tax to tier 1 capital: profit before tax / tier 1 capital (PTC)

(2) Return on average assets $(R O A A)$ : profit before tax/ average equity

Typically, the high profitability will increase the bank's equity value. This means that a larger buffer to absorb fluctuations in the river before the loss occurs. High profitability is usually a positive indicator relate to the bank's financial strength. It used to analyze the bank's profitability and operating efficiency.

$\diamond \quad$ Asset Quality (AQ) (\%)

Non-performing loan $(N P L)$ : non-performing loans/total loans

According several overseas studies, the history showed most of the poor quality of bank assets and mismanagement caused by their failure. Because of poor asset quality and credit losses adversely affect the bank's financial strength. In addition, the poor quality of assets will adversely affect the bank's financial strength. Therefore, the usual high non-performing loans (NPL) ratio is considered to be bank and one of the key failure warning signals. Ratios calculated by dividing non-performing loans to total non-performing loans portfolio. 
Table 4. Descriptive Statistics

\begin{tabular}{|l|l|l|l|l|l|l|}
\hline & CG & CAR & PTC & TA & $\begin{array}{l}\text { NPL } \\
x_{4}\end{array}$ & $\begin{array}{l}\text { ROAA } \\
\boldsymbol{x}_{5}\end{array}$ \\
\hline Mean & 2.166666667 & 3.822222222 & 4.45 & 4.166667 & 4.14444444 & 4.138888889 \\
\hline Standard Error & 0.027855261 & 0.064564412 & 0.058576 & 0.059743 & 0.04669208 & 0.069028862 \\
\hline Median & 2 & 4 & 5 & 4 & 4 & 4 \\
\hline Mode & 2 & 4 & 5 & 4 & 4 & 4 \\
\hline Standard Deviation & 0.373717546 & 0.86622249 & 0.785874 & 0.801535 & 0.62643999 & 0.926119367 \\
\hline Sample Variance & 0.139664804 & 0.750341403 & 0.617598 & 0.642458 & 0.39242706 & 0.857697083 \\
\hline Kurtosis & 1.268101314 & -0.14449984 & 0.37295 & 0.526294 & 0.08041954 & 2.475608191 \\
\hline Skewness & 1.803921999 & -0.428994274 & -1.19475 & -0.7716 & -0.2523665 & -1.390077609 \\
\hline Range & 1 & 4 & 3 & 4 & 3 & 4 \\
\hline Minimum & 2 & 1 & 2 & 1 & 2 & 1 \\
\hline Maximum & 3 & 5 & 5 & 5 & 5 & 5 \\
\hline Sum & 390 & 688 & 801 & 750 & 746 & 745 \\
\hline Count & 180 & 180 & 180 & 180 & 180 & 180 \\
\hline $\begin{array}{l}\text { Confidence } \\
\text { Level(95.0\%) }\end{array}$ & 0.054966938 & 0.127405306 & 0.115588 & 0.117891 & 0.09213774 & 0.136215029 \\
\hline
\end{tabular}

Descriptive statistics of the above data included sample means, maximum, minimum, standard deviation, skewness and kurtosis. The variables of CAR, PTC, TA, NPL and ROAA have negative skewness which indicated the fat tail on the left-hand side of the distribution.

We measure the corporate governance of bank. As presented in Table 2, the average corporate governance is 2.17; the maximum value is 3 and the minimum value is 2 .

About capital aspects, it used capital adequacy ratio which is showed the average 3.82 . The maximum value is 5 and the minimum is 1 . For the profitability, profit before tax to tier 1 capital (PTC) showed the average 4.45 and return on average assets (ROAA) showed the average 4.14 . The maximum value is 5 .

With regard to the asset quality, the non-performing loan to total loans $(N P L)$ has averaged 4.14. For asset size, measured by the total assets, the average is 4.17 . The maximum value is 5. 
Table 5.

t test for Independent Variables

\begin{tabular}{|l|l|l|l|l|l|}
\hline & CAR & PTC & TA & NPL & ROAA $x_{5}$ \\
& $x_{1}$ & $x_{2}$ & $x_{3}$ & $x_{4}$ & \\
\hline Calculated $t$ stat & 6.1838 & 4.3524 & 0.2727 & 0.0637 & 2.7438 \\
\hline$P(T<=$ t $)$ one-tail & $2.06 E-09$ & $1.13 E-05$ & 0.3927 & 0.4746 & $2.9363-35$ \\
\hline$t$ Critical one-tail & 1.6534 & 1.6534 & 1.6534 & 1.6534 & 1.6534 \\
\hline
\end{tabular}

Sample t-test and F-test were used to testing. The hypothesis is set for the t-test and F-test with $y$ to group $x_{1}$ to $x_{3}$. The null hypothesis is set independent variable $x$ do not positive significantly relate to the dependent variable $\mathrm{y}$. The alternative hypothesis is set independent variable $\mathrm{x}$ do positive significantly relate to the $\mathrm{y} . \mathrm{H}_{0}: \mu \mathrm{Y}-\mu \mathrm{X} \leq 0$ and $\mathrm{H}_{1}: \mu \mathrm{Y}-\mu \mathrm{X}>0$. Another hypothesis is set for the $y$ to group $x_{4}$ to $x_{5}$. The null hypothesis is set independent variable do not negative significantly relate to the dependent variable $y$. The alternative hypothesis is set independent variable $x$ do negative significantly relate to the $y$.

According to the result of $y$ to $x_{1}$, the $t$ static value is 6.1838 greater than $t$ Critical one tail 1.6534 and the means for $C A R$ is significantly different as $\mathrm{p}$ value is $2.064 E-09$. Thus, the null hypothesis is rejected. There is existed statistically significant relationship.

According to the result of $y$ to $x_{2}$, the t static value is 4.3524 greater than t Critical one tail 1.6534 and the means for PTC is significantly different as $\mathrm{p}$ value is $1.13 E-05$. Thus, the null hypothesis is rejected. There is existed statistically significant relationship.

According to the result of $y$ to $x_{3}$, the t static value is 0.2727 smaller than $t$ Critical one tail 1.6534 and the means for $T A$ is significantly different as p-value is 0.3927 . Thus, the null hypothesis is not rejected. There is existed not statistically significant relationship.

According to the result of $y$ to $x_{4}$, the $\mathrm{t}$ static value is 0.0637 smaller than t Critical one tail 1.6534 and the means for NPL is significantly different as p-value is 0.4746 . Thus, the null hypothesis is not rejected. There is existed not statistically significant relationship.

According to the result of $y$ to $x_{5}$, the t static value is 2.7438 greater than t Critical one tail 1.6534 and the means for $R O A A$ is significantly different as p-value is $2.9363-35$. Thus, the null hypothesis is rejected. There is existed statistically significant relationship.

Table 6.

F test for Independent Variables

\begin{tabular}{|l|l|l|l|l|l|}
\hline & CAR & PTC & TA & NPL & ROAA \\
& $\boldsymbol{x}_{\mathbf{1}}$ & $\boldsymbol{x}_{\mathbf{2}}$ & $\boldsymbol{x}_{\mathbf{3}}$ & $\boldsymbol{x}_{\mathbf{4}}$ & $\boldsymbol{x}_{\mathbf{5}}$ \\
\hline Calculated $F$ & 1.2149 & 0.6137 & 1.6371 & 0.4575 & 6.1411 \\
\hline$P(F<=$ f) one-tail & 0.0968 & 0.396 & 0.000525 & 1.2435 & $1.67 E-30$ \\
\hline F Critical one-tail & 1.2796 & 0.7815 & 1.2796 & 0.7815 & 1.2796 \\
\hline
\end{tabular}

For the output of $y$ to $x_{1}$, the F test is 1.2149 smaller than F Critical value one tail 1.2796 and the mean for the CAR is significantly different as p-value is 0.0968 . The null hypothesis is not 
rejected. There is existed not statistically significant relationship. For the output of $y$ to $x_{2}$, the $\mathrm{F}$ test is 0.6137 smaller than F Critical value one tail 0.7815 and the mean for the PTC is significantly different as p-value is 0.3960 . The null hypothesis is not rejected. There is existed not statistically significant relationship. For the output of $y$ to $x_{3}$, the F test is 1.6371 smaller than F Critical value one tail 1.2796 and the mean for the $T A$ is significantly different as p-value is 0.000525 . The null hypothesis is rejected. There is existed statistically significant relationship. For the output of $y$ to $x_{4}$, the $\mathrm{F}$ test is 0.4575 smaller than F Critical value one tail 0.7815 and the mean for the $T A$ is significantly different as p-value is 1.2435. The null hypothesis is not rejected. There is existed not statistically significant relationship. For the output of $y$ to $x_{5}$, the $\mathrm{F}$ test is 6.1411 greater than $\mathrm{F}$ Critical value one tail 1.2796 and the mean for the $T A$ is significantly different as p-value is $1.67 \mathrm{E}-30$. The null hypothesis is rejected. There is existed statistically significant relationship.

Table 7.

\begin{tabular}{|l|l|l|l|l|l|}
\hline & $y$ to $x_{\mathbf{1}}$ & $y$ to $x_{\mathbf{2}}$ & $y$ to $x_{3}$ & $y$ to $x_{4}$ & $y$ to $x_{5}$ \\
\hline Calculated $\chi^{2}$ & 0.683 & 0.393 & 8 & 6.237 & 6.338 \\
\hline -value & 0.4563 & 0.5568 & 0.0035 & 0.0182 & 0.0178 \\
\hline Degree of freedom & 1 & 1 & 1 & 1 & 1 \\
\hline Significance level & 0.05 & 0.05 & 0.05 & 0.05 & 0.05 \\
\hline $\begin{array}{l}\chi^{2} \text { square Critical } \\
\text { value }\end{array}$ & 3.563 & 3.563 & 3.563 & 3.563 & 3.563 \\
\hline
\end{tabular}

Chi-square test applied in this study, there are two groups set relying on above or below means to each variable. The average of $y$ is 2.1667 , and the means of $x_{1}$ to $x_{5}$ is $3.8222,4.45$, $4.167,4.144$ and 4.139 respectively. In the test, the group is defined relying on the means of $y$. Each individual variable direction $x$ is considered in the $y$ situation. There are two groups formed to each variable $x$ of above and below mean. The individual variables $x$ values for each group of overlapping set of $y$ variable, they will be paired in the same group. Hypothesis is set. Null hypothesis: the corporate governance $y$ is not depended of independent value $x$ individually. Alternative hypothesis: the corporate governance $y$ is depended of independent value $x$ individually. Group 1 is defined as below means and group 2 is defined as above means. There are 15 banks have set corporate governance lower than the average, and 15 banks have set upper the means. The degrees of random set $(2-1) *(2-1)=1$. The level of significance is set $5 \%$ and the degrees of freedom are 1 . For the output $y$ to $x_{1}, x^{2}$ statistic is 0.683 does not exceed critical value 3.563 . So we can accept the null hypothesis that the $y$ is not depended of independent $x_{1}$ value. But, the p-value of two-tailed equals 0.4629 . So it is not statistically significant. For the output $y$ to $x_{2}$, the $x^{2}$ statistic is 0.393 and do not exceed the critical value. So we can accept null hypothesis. There is existed not statistically significant relationship. For the output $y$ to $x_{3}$, the $x^{2}$ equals 8 ; it exceeds the critical value, so we can accept the null hypothesis. And the two-tailed p-value is 0.0035 . So it is statistically significant. For the output $y$ to $x_{4}, x^{2}$ statistic is 6.237 ; it exceeds the critical value, so we can reject null hypothesis. So it is statistically significant. And the two-tailed p-value is 0.0182 . For the output $y$ to $x_{5}, x^{2}$ statistic is 6.338 ; it exceeds the critical value, and the two-tailed 


\section{Macrothink}

p-value is 0.0178 . So we can reject null hypothesis. So it is statistically significant.

The statistical method of t-test with hypothesis is used to point out the correlation between the full data of the dependent and independent variables. In the view to the variables $x_{1}$ to $x_{5}$, null hypothesis $\left(\mathrm{H}_{0}\right)$ as independent variables $x$ do not exist influence to the dependent variable $y$ significantly, whereas the another hypothesis $\left(\mathrm{H}_{1}\right)$ is independent variable $x$ affect to the dependent variable $y$ significantly. The Explanatory of $\mathrm{R}^{2,}$ it used to measures explain the percentage of the independent variable of the dependent variable.

The correlation and regression analysis is performed on the dependent variable with $C G, B S$ and $B M$ which is used to test the relationship between the independent variables (Capital, Asset Size, Profitability, Asset Quality) with financial performance.

\section{Part 1 (a) Hypothesis testing of this study}

The following are the hypothesis of this study based on the various variables:

a) Corporate Governance has a statistically significant effect on Capital of banks.

b) Corporate Governance has a statistically significant effect on Profitability of banks.

c) Corporate Governance has a statistically significant effect on Asset Size of banks.

d) Corporate Governance has a statistically significant effect on Asset Quality of banks.

\section{Part 2 (b) Hypothesis testing of this study}

The following are the hypothesis of this study based on the various variables:

a) Board Size has a statistically significant effect on Capital of banks.

b) Board Size has a statistically significant effect on Profitability of banks.

c) Board Size has a statistically significant effect on Asset Size of banks.

d) Board Size has a statistically significant effect on Asset Quality of banks.

\section{Part 3 (c) Hypothesis testing of this study}

The following are the hypothesis of this study based on the various variables:

a) Board Meeting has a statistically significant effect on Capital of banks.

b) Board Meeting has a statistically significant effect on Profitability of banks.

c) Board Meeting has a statistically significant effect on Asset Size of banks.

d) Board Meeting has a statistically significant effect on Asset Quality of banks. 
Table 8. Correlation of Parameters

\section{Part 1}

(a)

\begin{tabular}{|c|c|c|c|c|c|c|}
\hline & $\begin{array}{l}C G \\
y\end{array}$ & $\begin{array}{r}\text { CAR } \\
\\
x_{1} \\
\end{array}$ & $\begin{array}{l}P T C \\
x_{2} \\
\end{array}$ & $\begin{array}{l}A S \\
x_{3}\end{array}$ & $\begin{array}{l}N P L \\
x_{4} \\
\end{array}$ & $\begin{array}{l}\text { ROAA } \\
x_{5}\end{array}$ \\
\hline$C G$ & 1 & & & & & \\
\hline CAR & 0.161069 & 1 & & & & \\
\hline PTC & 0.313859 & -0.35781 & 1 & & & \\
\hline$T A$ & 0.167851 & -0.28698 & 0.394668 & 1 & & \\
\hline NPL & 0.063635 & 0.243197 & -0.28029 & -0.15947 & 1 & \\
\hline ROAA & 0.094157 & -0.03869 & 0.236033 & 0.593291 & -0.10218 & 1 \\
\hline
\end{tabular}

The table showed correlation coefficients between the dependent and independent variable in these articles. The examination of the correlation matrix showed that there is a significant relationship between the dependent variable $(C G)$ and the variables related to the bank's financial performance which are $C A R, P T C, T A, N P L$ and $R O A A$. It showed that the corporate governance is positive direction to $C A R, P T C, T A, N P L$ and $R O A A$.

\section{Part 2}

(b)

\begin{tabular}{|l|l|l|l|l|l|l|}
\hline & \multicolumn{1}{l|}{ BS } & \multicolumn{1}{l|}{ CAR } & PTC & AS & NPL & $R O A A$ \\
\hline BS & 1 & $x_{1}$ & $x_{2}$ & $x_{3}$ & $x_{4}$ & $x_{5}$ \\
\hline CAR & -0.29483 & 1 & & & & \\
\hline PTC & 0.243626 & -0.28227 & 1 & & & \\
\hline TA & -0.07259 & -0.21428 & 0.212768 & 1 & & \\
\hline NPL & -0.00462 & -0.27994 & 0.035715 & 0.278679 & 1 & \\
\hline & & & & & & \\
\hline ROAA & 0.152637 & -0.09574 & 0.06877 & -0.00384 & -0.00946 & 1 \\
\hline
\end{tabular}

The examination of the correlation matrix showed that there is a significant relationship between the dependent variable $(B S)$ and the variables related to the bank's financial performance which are $P T C$ and $R O A A$. It showed that board size is negative direction to $C A R, T A$ and NPL.

\section{Part 3}

(c) 


\begin{tabular}{|c|c|c|c|c|c|c|}
\hline & \begin{tabular}{|l}
$B M$ \\
$y^{2}$
\end{tabular} & $\begin{array}{r}\text { CAR } \\
x_{1} \\
\end{array}$ & \begin{tabular}{|l|} 
PTC \\
$x_{2}$ \\
\end{tabular} & $\begin{array}{l}A S \\
x_{3} \\
\end{array}$ & \begin{tabular}{|l|}
$N P L$ \\
$x_{4}$ \\
\end{tabular} & \begin{tabular}{|l|}
$R O A A$ \\
$x_{5}$
\end{tabular} \\
\hline$B M$ & 1 & & & & & \\
\hline CAR & -0.3864 & 1 & & & & \\
\hline PTC & 0.32933 & -0.2823 & 1 & & & \\
\hline$T A$ & 0.29448 & -0.2143 & 0.21277 & 1 & & \\
\hline NPL & -0.0168 & -0.2799 & 0.03571 & 0.27868 & 1 & \\
\hline ROAA & 0.34492 & -0.0957 & 0.06877 & -0.0038 & -0.0095 & 1 \\
\hline
\end{tabular}

The examination of the correlation matrix showed that there is a significant relationship between the dependent variable $(B M)$ and the variables related to the bank's financial performance which are $P T C, T A$ and $R O A A$. It showed that board meeting is negative direction to $C A R$ and $N P L$.

Table 9. Linear Regressions Model

\section{Part 1}

(a)

(Dependant variable: $C G)$

\begin{tabular}{|l|l|l|l|l|l|}
\hline & & \multicolumn{1}{|c|}{$\boldsymbol{R}^{\mathbf{2}}$} & $\boldsymbol{F}$ & $\boldsymbol{t}$ Stat & \multicolumn{1}{|c|}{-value } \\
\hline Capital & CAR & 0.025943 & 4.7408615 & 2.17735 & 0.03077 \\
\hline Asset Size & TA & 0.028174 & 5.1603436 & 2.27164 & 0.02431 \\
\hline Asset Quality & NPL & 0.004049 & 0.7237151 & 0.85071 & 0.39607 \\
\hline Profitability & PTC & 0.098507 & 19.450331 & 4.41025 & $1.80 E-05$ \\
\hline & ROAA & 0.008866 & 1.5921869 & 1.26182 & 0.20866 \\
\hline
\end{tabular}

Based on the above table, the linear regression analysis showed in the following:

According to capital adequacy ratio result, $\mathrm{R}^{2}$ is 0.0259 ; the regression relationship is very weak; $2.5 \%$ of the variability in the $C A R$ can be explained by the linear relationship between the corporate governance and the capital. The F test is 4.740 is greater than 3.894. The t static value is 2.177 greater than 1.973 and p-value smaller than the level of significance $5 \%$. Thus, the null hypothesis is rejected. There is existed statistically significant relationship. According to profit before tax to tier one capital ratio result, $\mathrm{R}^{2}$ is 0.0985 ; the regression relationship is very weak; $9.8 \%$ of the variability in the PTC can be explained by the linear relationship between the corporate governance and profitability. The F test is 19.450 is greater than 3.894.The $t$ static value is 4.410 greater than 1.973 and $p$-value smaller than the level of significance $5 \%$. Thus, the null hypothesis is rejected. There is existed statistically significant relationship.

According to total assets result, $\mathrm{R}^{2}$ is 0.0282 ; the regression relationship is very weak; $2.8 \%$ of the variability in the total assets explained by the linear relationship between the corporate governance and asset size. The $F$ test is 5.1603 is greater than 3.894 . The $t$ static value is 
2.272 greater than 1.973 and p-value smaller than the level of significance $5 \%$. Thus, the null hypothesis is rejected. There is existed statistically significant relationship. According to non-performing loans result, $\mathrm{R}^{2}$ is 0.03796 ; the regression relationship is very weak; $0.4 \%$ of the variability in the total assets explained by the linear relationship between the corporate governance and asset size. The $\mathrm{F}$ test is 0.724 is greater than 3.894. The $t$ static value is 0.851 smaller than 1.973 and p-value greater than the level of significance $5 \%$. Thus, the null hypothesis is not rejected. There is existed not statistically significant relationship.

According to return on average assets result, $\mathrm{R}^{2}$ is 0.004 ; the regression relationship is very weak; $0.4 \%$ of the variability in the total assets explained by the linear relationship between the corporate governance and asset size. The F test is 1.592 is greater than 3.894. The $t$ static value is 1.261 smaller than 1.973 and p-value greater than the level of significance $5 \%$. Thus, the null hypothesis is not rejected. There is existed not statistically significant relationship. There is statistically significant relationship between $C A R, P T C, T A, R O A A$ and corporate governance. $N P L$ is existed not statistically significant relationship between corporate governance.

\section{Part 2}

(b)

(Dependant variable: $B S)$

\begin{tabular}{|l|l|l|l|l|l|}
\hline & & \multicolumn{1}{|c|}{$\boldsymbol{R}^{\mathbf{2}}$} & $\boldsymbol{F}$ & $\boldsymbol{t}$ Stat & P-value \\
\hline Capital & CAR & 0.08693 & 16.94591 & -4.11654 & 0.36687 \\
\hline Asset Size & TA & 0.00527 & 0.94286 & -0.97101 & 0.33286 \\
\hline Asset Quality & NPL & 0.00002 & 0.00380 & -0.06166 & 0.95091 \\
\hline Profitability & PTC & 0.05935 & 11.23157 & 3.35135 & 0.00098 \\
\hline & ROAA & 0.02330 & 4.24597 & 2.06058 & 0.04080 \\
\hline
\end{tabular}

Based on the above table, the linear regression analysis showed in the following:

According to capital adequacy ratio result, $\mathrm{R}^{2}$ is 0.0869 ; the regression relationship is very weak; $8.69 \%$ of the variability in the $C A R$ can be explained by the linear relationship between the board size and the capital. The F test is 16.946 is greater than 3.894. The $t$ static value is -4.112 smaller than 1.973 and p-value greater than the level of significance $5 \%$. Thus, the null hypothesis is not rejected. There is existed not statistically significant relationship. According to profit before tax to tier one capital ratio result, $\mathrm{R}^{2}$ is 0.059 ; the regression relationship is very weak; $5.90 \%$ of the variability in the PTC can be explained by the linear relationship between the board size and profitability. The F test is 11.23 is greater than 3.894 . The $t$ static value is 3.351 greater than 1.973 and p-value greater than the level of significance $5 \%$. Thus, the null hypothesis is rejected. There is existed statistically significant relationship.

According to total assets result, $\mathrm{R}^{2}$ is 0.0053 ; the regression relationship is very weak; $0.53 \%$ of the variability in the total assets explained by the linear relationship between the board size and asset size. The $F$ test is 0.00380 is smaller than 3.8942 . The $t$ static value is -0.971 smaller than 1.973 and p-value greater than the level of significance $5 \%$. Thus, the null 
hypothesis is not rejected. There is existed not statistically significant relationship. According to non-performing loans result, $\mathrm{R}^{2}$ is 0.00002 ; the regression relationship is very weak; $0 \%$ of the variability in the total assets explained by the linear relationship between the board size and asset size. The $\mathrm{F}$ test is 0.724 is smaller than 3.894 . The $\mathrm{t}$ static value is -0.062 smaller than 1.973 and p-value greater than the level of significance $5 \%$. Thus, the null hypothesis is not rejected. There is existed not statistically significant relationship.

According to return on average assets result, $\mathrm{R}^{2}$ is 0.023 ; the regression relationship is very weak; $2.3 \%$ of the variability in the total assets explained by the linear relationship between the board size and asset size. The F test is 4.246 is greater than 3.8942 . The t static value is 2.061 greater than 1.973 and p-value smaller than the level of significance 5\%. Thus, the null hypothesis is rejected. There is existed statistically significant relationship.

There is statistically significant relationship between $P T C, R O A A$ and board size. NPL, CAR and $T A$ are existed not statistically significant relationship between board sizes.

\section{Part 3}

(c)

\section{(Dependant variable: $\mathrm{BM}$ )}

\begin{tabular}{|l|l|l|l|l|l|}
\hline & & \multicolumn{1}{|c|}{$\boldsymbol{R}^{2}$} & $\boldsymbol{F}$ & $\boldsymbol{t}$ Stat & P-value \\
\hline Capital & CAR & 0.14931 & 31.2427 & -5.5895 & 0.67687 \\
\hline Asset Size & TA & 0.08672 & 16.9019 & 4.1112 & 0.02586 \\
\hline Asset Quality & NPL & 0.00028 & 16.5832 & -0.224 & 0.85191 \\
\hline Profitability & PTC & 0.10846 & 21.6537 & 4.65336 & 0.00139 \\
\hline & ROAA & 0.11897 & 24.036 & 4.90265 & 0.03070 \\
\hline
\end{tabular}

Based on the above table, the linear regression analysis showed in the following:

According to capital adequacy ratio result, $\mathrm{R}^{2}$ is 0.1493 ; the regression relationship is very weak; $14.93 \%$ of the variability in the $C A R$ can be explained by the linear relationship between the board meeting and the capital. The $\mathrm{F}$ test is 31.243 is greater than 3.894 . The $\mathrm{t}$ static value is -5.590 smaller than 1.973 and p-value greater than the level of significance $5 \%$. Thus, the null hypothesis is not rejected. There is existed not statistically significant relationship. According to profit before tax to tier one capital ratio result, $\mathrm{R}^{2}$ is 0.1085 ; the regression relationship is very weak; $10.85 \%$ of the variability in the PTC can be explained by the linear relationship between the board meeting and profitability. The $\mathrm{F}$ test is 21.654 is greater than 3.8942.The t static value is 4.653 greater than 1.973 and p-value smaller than the level of significance $5 \%$. Thus, the null hypothesis is rejected. There is existed statistically significant relationship.

According to total assets result, $\mathrm{R}^{2}$ is 0.0867 ; the regression relationship is very weak; $8.67 \%$ of the variability in the total assets explained by the linear relationship between the board meeting and asset size. The F test is 16.902 is greater than 3.8942. The t static value is 4.111 greater than 1.973 and p-value smaller than the level of significance 5\%. Thus, the null 
hypothesis is rejected. There is existed statistically significant relationship. According to non-performing loans result, $\mathrm{R}^{2}$ is 0.00028 ; the regression relationship is very weak; $0.028 \%$ of the variability in the total assets explained by the linear relationship between the board meeting and asset size. The F test is 16.583 is greater than 3.894 . The $t$ static value is -0.224 smaller than 1.973 and p-value greater than the level of significance $5 \%$. Thus, the null hypothesis is not rejected. There is existed not statistically significant relationship.

According to return on average assets result, $\mathrm{R}^{2}$ is 0.1190 ; the regression relationship is very weak; $11.90 \%$ of the variability in the total assets explained by the linear relationship between the board meeting and asset size. The $\mathrm{F}$ test is 24.036 is greater than 3.8942 . The $\mathrm{t}$ static value is 4.903 greater than 1.973 and p-value smaller than the level of significance 5\%. Thus, the null hypothesis is rejected. There is existed statistically significant relationship.

There is statistically significant relationship between PTC, TA, ROAA and board meeting. $N P L$ and $C A R$ are existed not statistically significant relationship between board meetings.

\section{Multiple linear regression models}

Multiple linear regression models are an attempt to show two or more fit the observed data plotted as a linear equation of the explanatory variables and the relationship between the dependent variable.

To examine how the corporate governance, board size and board meeting to affect the bank's financial performance of the Asian banks, so we will set 3 multiple regression equation is represented by $y=\beta_{0}+\beta_{1} x_{1}+\beta_{2} x_{2}+\beta_{3} x_{3}+\beta_{4} x_{4}+\beta_{5} x_{5}$ where the dependent variable $y$ is the value for the corporate governance, board size and board meeting; $\beta$ is the Slope means Beta Coefficient for the indicator individually. According to the multiple regressions, the formula for the regression testing is for part 1: Corporate Governance $(C G)=\beta_{0}+\beta_{1}$ Capital $(C A R)$ $+\beta_{2}$ Profitability $(P T C)+\beta_{3}$ Asset SIZE $(T A)+\beta_{4}$ Asset Quality $(N P L)+\beta_{5}$ Profitability $(R O A A)$

The formula for the regression testing is for part 2: Board Size $(B S)=\beta_{0}+\beta_{1}$ Capital $(C A R)$ $+\beta_{2}$ Profitability $(P T C)+\beta_{3}$ Asset SIZE $(T A)+\beta_{4}$ Asset Quality $(N P L)+\beta_{5}$ Profitability $(R O A A)$

The formula for the regression testing is for part 3: Board Meeting $(B M)=\beta_{0}+\beta_{1}$ Capital $(C A R)+\beta_{2}$ Profitability $(P T C)+\beta_{3}$ Asset SIZE $(T A)+\beta_{4}$ Asset Quality $(N P L)+\beta_{5}$ Profitability $(R O A A)$

Table 10.

\section{Part 1}

(a) (Dependant variable: $C G$ ) 
SUMMARY OUTPUT

\begin{tabular}{ll}
\hline \multicolumn{2}{l}{ Regression Statistics } \\
\hline Multiple R & 0.4591595 \\
$R$ Square & 0.2108274 \\
Adjusted R Square & 0.1881501 \\
Standard Error & 0.3367297 \\
Observations & 180 \\
\hline
\end{tabular}

ANOVA

\begin{tabular}{llllll}
\hline & $d f$ & $S S$ & $M S$ & $F$ & $\begin{array}{l}\text { Significance } \\
F\end{array}$ \\
\hline Regression & 5 & 5.27069 & 1.0541 & 9.29682 & $7.28 E-08$ \\
Residual & 174 & 19.7293 & 0.1134 & & \\
Total & 179 & 25 & & & \\
\hline
\end{tabular}

\begin{tabular}{lllllll}
\hline & Coefficients & $\begin{array}{l}\text { Standard } \\
\text { Error }\end{array}$ & t Stat & P-value & Lower 95\% & $\begin{array}{l}\text { Upper } \\
95 \%\end{array}$ \\
\hline$C G$ & 0.265645 & 0.31821 & 0.8348 & 0.40498 & -0.3624 & 0.8937 \\
CAR & 0.139926 & 0.03249 & 4.3068 & $2.76 E-05$ & 0.0758 & 0.20405 \\
PTC & 0.198893 & 0.03702 & 5.3728 & $2.46 E-07$ & 0.12583 & 0.27196 \\
$T A$ & 0.0740828 & 0.04249 & 1.7435 & 0.08301 & -0.0098 & 0.15795 \\
NPL & 0.0714471 & 0.04244 & 1.6833 & 0.09411 & -0.0123 & 0.15522 \\
ROAA & -0.029879 & 0.03433 & -0.8703 & 0.38536 & -0.0976 & 0.03789 \\
\hline
\end{tabular}

$C G=0.2656+(0.1399) C A R+(0.1989) P T C+(0.0740) T A+(0.0714) N P L+(-0.0299)$ ROAA

According to ANOVA, F-test statistic is 9.2968 with p-value of $7.28087 E-08$. Since the $\mathrm{p}$-value is less than 0.05 , we reject the null hypothesis that regression parameters are not zero at significance level 0.05 . F value is greater than 2.2660. It concluded that the parameters are jointly statistically significant at significance level 0.05 . CAR has estimated standard error of 0.0325 ; the t static value is 4.3068 greater than 1.9737 and $\mathrm{p}$ - value smaller than the level of significance $5 \%$. Thus, the null hypothesis is rejected. There is existed statistically significant relationship. PTC has estimated standard error of 0.0370 ; the $t$ static value is 5.3728 greater than 1.9737 and p- value smaller than the level of significance $5 \%$. Thus, the null hypothesis is rejected. There is existed statistically significant relationship. TA has estimated standard error of 0.0425 ; the $t$ static value is 1.7435 smaller than 1.9737 and $p$ - value greater than the level of significance $5 \%$. Thus, the null hypothesis is not rejected. There is existed not statistically significant relationship. NPL has estimated standard error of 0.0424 ; the t static value is 1.6833 smaller than 1.9737 and $\mathrm{p}$ - value greater than the level of significance $5 \%$. Thus, the null hypothesis is not rejected. There is existed not statistically significant relationship. ROAA has estimated standard error of 0.0343 ; the $\mathrm{t}$ static value is -0.8703 
smaller than 1.9737 and p-value greater than the level of significance $5 \%$. Thus, the null hypothesis is not rejected. There is existed not statistically significant relationship. There is statistically significant relationship between $C A R, P T C$ and corporate governance. TA, NPL, $R O A A$ are not statistically significant relationship between corporate governance.

\section{Part 2}

(b) (Dependant variable: $B S$ )

SUMMARY OUTPUT

\begin{tabular}{lr}
\hline Regression Statistics \\
\hline Multiple $R$ & 0.39681382 \\
$R$ Square & 0.15746121 \\
Adjusted & $R$ \\
Square & 0.13325032 \\
Standard Error & 2.99981948 \\
Observations & 180 \\
\hline
\end{tabular}

ANOVA

\begin{tabular}{llllll}
\hline & & & & \multicolumn{2}{l}{ Significance } \\
& $d f$ & $S S$ & $M S$ & $F$ & $F$ \\
\hline Regression & 5 & 292.6329 & 58.526586 .503736 & $1.43212 E-05$ \\
Residual & 174 & 1565.812 & 8.998917 & \\
Total & 179 & 1858.444 & & \\
\hline
\end{tabular}

\begin{tabular}{|c|c|c|c|}
\hline & Standard & & \\
\hline & Coefficients Error & P-value Lower 95\% & Upper 95\% \\
\hline$B S$ & 17.85371581 .471705 & $12.131316 .16 E-2514.94902326$ & 20.75840827 \\
\hline$C A R$ & -30.2934978 .370826 & $-3.618940 .068388-46.81492502$ & -13.77206853 \\
\hline PTC & 5.567606212 .12297 & 2.6225550 .0095011 .377517673 & 9.757694747 \\
\hline$T A$ & $-9.95 E-07 \quad 4.62 E-07$ & $-2.155150 .062525-1.90617 E-06$ & $-8.37734 E-08$ \\
\hline$N P L$ & -15.70628827 .36175 & $-0.574020 .566693-69.70993758$ & 38.29736063 \\
\hline$R O A A$ & 2.533505181 .58608 & $1.5973380 .112005-0.596927018$ & 5.663937377 \\
\hline
\end{tabular}

According to ANOVA, F-test statistic is 6.5037 with p-value of $1.43212 E-05$. Since the $\mathrm{p}$-value is less than 0.05 , we reject the null hypothesis that regression parameters are not zero at significance level 0.05 . F value is greater than 2.2660 . It concluded that the parameters are jointly statistically significant at significance level 0.05 . CAR has estimated standard error of 8.3708; the $t$ static value is -3.6189 smaller than 1.9737 and $p$-value greater than the level of significance $5 \%$. Thus, the null hypothesis is rejected. There is existed statistically significant relationship. PTC has estimated standard error of 2.1229 ; the t static value is 2.6226 greater 
than 1.9737 and $p$ - value smaller than the level of significance 5\%. Thus, the null hypothesis is rejected. There is existed statistically significant relationship. $T A$ has estimated standard error of 4.62E-07; the $t$ static value is -2.1551 smaller than 1.9737 and $p$-value greater than the level of significance 5\%. Thus, the null hypothesis is not rejected. There is existed not statistically significant relationship. $N P L$ has estimated standard error of 27.3618 ; the t static value is -0.5740 smaller than 1.9737 and p-value greater than the level of significance $5 \%$. Thus, the null hypothesis is not rejected. There is existed not statistically significant relationship. ROAA has estimated standard error of 1.5861; the t static value is 1.5973 smaller than 1.9737 and p-value greater than the level of significance 5\%. Thus, the null hypothesis is not rejected. There is existed not statistically significant relationship. There is statistically significant relationship between CAR, PTC and board size. TA, NPL, ROAA are not statistically significant relationship between board sizes.

\section{Part 3}

(c) (Dependant variable: $B M$ )

SUMMARY OUTPUT

\begin{tabular}{ll}
\hline \multicolumn{2}{l}{ Regression Statistics } \\
\hline Multiple R & 0.595169 \\
$R$ Square & 0.354226 \\
Adjusted R Square & 0.335669 \\
Standard Error & 2.81016 \\
Observations & 180 \\
\hline
\end{tabular}

ANOVA

\begin{tabular}{llllll}
\hline & $d f$ & $S S$ & $M S$ & $F$ & $\begin{array}{l}\text { Significance } \\
F\end{array}$ \\
\hline Regression & 5 & 753.7225013 & 150.7445 & 19.08884 & $4.067 E-15$ \\
Residual & 174 & 1374.077499 & 7.896997 & & \\
Total & 179 & 2127.8 & & & \\
\hline
\end{tabular}

\begin{tabular}{|c|c|c|c|c|c|c|}
\hline & Coefficients & $\begin{array}{l}\text { Standard } \\
\text { Error }\end{array}$ & $t$ Stat & P-value & Lower 95\% & Upper 95\% \\
\hline$B M$ & 10.69752 & 1.378658734 & 7.759365 & $6.94 E-13$ & 7.9764698 & 13.418564 \\
\hline$C A R$ & -35.7165 & 7.841591247 & -4.55475 & 9.833382 & -51.1934 & -20.23964 \\
\hline PTC & 5.461584 & 1.988748255 & 2.746242 & 0.006662 & 1.5364084 & 9.3867592 \\
\hline$T A$ & $1.6 E-06$ & 4.324832654 & 3.692684 & 0.000297 & $7.434 E-07$ & $2.451 E-06$ \\
\hline$N P L$ & -67.4449 & 25.63183618 & -2.63129 & 0.08927 & -118.0342 & -16.85556 \\
\hline$R O A A$ & 7.339436 & 1.485801915 & 4.939714 & $1.83 E-06$ & 4.4069217 & 10.271951 \\
\hline
\end{tabular}

$B M=10.6975+(-35.7165) C A R+5.4616 P T C+1.6 \mathrm{E}-06 T A+(-67.4449) N P L+7.3394$ $R O A A$ 
According to ANOVA, F-test statistic is 19.0888 with p-value of $4.067 E-15$. Since the p-value is less than 0.05 , we reject the null hypothesis that regression parameters are not zero at significance level 0.05 . F value is greater than 2.2660. It concluded that the parameters are jointly statistically significant at significance level 0.05 . CAR has estimated standard error of 7.8416; the t static value is -4.5548 smaller than 1.9737 and $p$-value greater than the level of significance $5 \%$. Thus, the null hypothesis is not rejected. There is existed not statistically significant relationship. PTC has estimated standard error of 1.9887; the t static value is 2.7462 greater than 1.9737 and $p$ - value smaller than the level of significance $5 \%$. Thus, the null hypothesis is rejected. There is existed statistically significant relationship. TA has estimated standard error of 4.3248; the t static value is 3.6927 greater than 1.9737 and p-value smaller than the level of significance 5\%. Thus, the null hypothesis is rejected. There is existed statistically significant relationship. $N P L$ has estimated standard error of 25.6318; the $\mathrm{t}$ static value is -2.6312 smaller than 1.9737 and $\mathrm{p}$-value greater than the level of significance $5 \%$. Thus, the null hypothesis is not rejected. There is existed not statistically significant relationship. ROAA has estimated standard error of 1.4858; the $\mathrm{t}$ static value is 4.9397 greater than 1.9737 and p-value smaller than the level of significance $5 \%$. Thus, the null hypothesis is rejected. There is existed statistically significant relationship. There is statistically significant relationship between $P T C, T A, R O A A$ and board meeting. $C A R$ and $N P L$ are not statistically significant relationship between board meetings.

Table 11. Summary of Outcomes (Coefficient)

\section{Part 1}

(a)

\begin{tabular}{|lc|l|l|}
\hline \multicolumn{2}{|l|}{ Variables } & Coefficients & P-value \\
\hline CAR & $\boldsymbol{x}_{\mathbf{1}}$ & 0.139926 & $2.76 E-05$ \\
\hline PTC & $\boldsymbol{x}_{\mathbf{2}}$ & 0.198893 & $2.46 E-07$ \\
\hline AS & $\boldsymbol{x}_{\mathbf{3}}$ & 0.0740828 & 0.08301025 \\
\hline NPL & $\boldsymbol{x}_{\mathbf{4}}$ & 0.0714471 & 0.09410908 \\
\hline ROAA & $\boldsymbol{x}_{\mathbf{5}}$ & -0.029879 & 0.38535758 \\
\hline
\end{tabular}

\section{*significant at $5 \%$ level}

The coefficient, it used to measures the level of the variability of each independent variable with the dependent variable. Additional, the positive and negative sign is used to indicate the direction of the effect on the coefficient. A negative sign means that the coefficients of the independent variables are reduced from the size of the dependent variable. The term of multicollinearity is refers to the correlation among the independent variables. The coefficient of $y$ to $x_{1}$ is 0.1399 and the p-value is $2.76 E-05$. The coefficient of $y$ to $x_{2}$ is 0.1989 and the $\mathrm{p}$-value is $2.46 E-07$. The coefficient of $\mathrm{y}$ to $x_{3}$ is 0.1989 and the $\mathrm{p}$-value is $2.46 E-07$. The coefficient of $y$ to $x_{4}$ is 0.0714 and the p-value is 0.094 . The coefficient of $y$ to $x_{5}$ is -0.030 and the p-value is 0.3854 . According to the tests, it showed that CAR, PTC, AS and NPL are positive coefficient to corporate governance. But, ROAA are negative coefficient to corporate governance 


\section{Part 2}

(b)

\begin{tabular}{|lc|l|l|}
\hline \multicolumn{2}{|l|}{ Variables } & Coefficients & P-value \\
\hline CAR & $\boldsymbol{x}_{\mathbf{1}}$ & -30.293497 & 0.068388 \\
\hline PTC & $\boldsymbol{x}_{\mathbf{2}}$ & 5.56760621 & 0.009501 \\
\hline AS & $\boldsymbol{x}_{\mathbf{3}}$ & $-9.95 E-07$ & 0.062525 \\
\hline NPL & $\boldsymbol{x}_{\mathbf{4}}$ & -15.706288 & 0.566693 \\
\hline ROAA & $\boldsymbol{x}_{\mathbf{5}}$ & 2.53350518 & 0.112005
\end{tabular}

\section{*significant at $5 \%$ level}

The above table exhibited simple correlation matrix among research variables for the sake of determining the existence of any multi-co-linearity problem before the regression analysis could be carried out. It was argued that a multi-co-linearity problem existed when correlation scores are 0.8 or greater (Cooper and Schindler, 2003). The term of multicollinearity is refers to the correlation among the independent variables. The coefficient of $y$ to $x_{1}$ is -30.2935 and the $\mathrm{p}$-value is 0.0684 . The coefficient of $y$ to $x_{2}$ is 5.5676 and the p-value is 0.0095 . The coefficient of $y$ to $x_{3}$ is $-9.95 \mathrm{E}-07$ and the p-value is 0.0625 . The coefficient of $y$ to $x_{4}$ is -15.7063 and the p-value is 0.5667 . The coefficient of $y$ to $x_{5}$ is 2.5335 and the $p$-value is 0.1120. According to the tests, it showed that $P T C$ and $R O A A$ are positive coefficient to board size. But, $C A R, A S$ and $N P L$ are negative coefficient to board size.

\section{Part 3}

(c)

\begin{tabular}{|c|c|c|c|}
\hline \multicolumn{2}{|c|}{ Variables } & Coefficients & P-value \\
\hline CAR & $x_{1}$ & -35.7165 & 9.833382 \\
\hline PTC & $x_{2}$ & 5.461584 & 0.006662 \\
\hline$A S$ & $x_{3}$ & $1.60 E-06$ & 0.000297 \\
\hline NPL & $x_{4}$ & -67.4449 & 0.08927 \\
\hline ROAA & $x_{5}$ & 7.339436 & $1.83 E-06$ \\
\hline
\end{tabular}

\section{*significant at $5 \%$ level}

The coefficient of $y$ to $x_{1}$ is -35.7165 and the p-value is 9.8334 . The coefficient of $y$ to $x_{2}$ is 5.4616 and the p-value is 0.0067 . The coefficient of $y$ to $x_{3}$ is $1.60 \mathrm{E}-06$ and the p-value is 0.0003 . The coefficient of $y$ to $x_{4}$ is -67.4449 and the p-value is 0.0893 . The coefficient of $y$ to $x_{5}$ is 7.3394 and the p-value is $1.83 E-06$. According to the tests, it showed that PTC, $A S$ and $R O A A$ are positive coefficient to board meeting. But, $C A R$ and $N P L$ are negative coefficient to board meeting.

\section{Conclusions and Recommendations}

We can know corporate governance how to effect corporate or banks. Corporate governance 
can bring out the positive or negative influence to the banks in many situations such as goodwill and financial performance. In the study, we used various independent variables to represent bank's performance or condition such as financial ratio. Bank's financial condition is the strongest objective indicator of creditworthiness. Many financial ratios such as cost to income ratio or return on average equity can use to test Capital, Profitability, Asset Quality and Asset Size. But, this study mainly used capital adequacy ratio $(C A R)$, total assets $(T A)$, and non-performing loans $(N P L)$, profit before tax to tier 1 capital $(P T C)$ and return on average assets $(R O A A)$. Because we considered the above financial ratios are more significant to represent bank's financial performance.

The testing results indicated there is statistically significant relationship between $C A R, P T C$ and corporate governance. TA, NPL, ROAA are not statistically significant relationship between corporate governance. There is statistically significant relationship between $C A R$, $P T C$ and board size. TA, NPL, ROAA are not statistically significant relationship between board sizes. There is statistically significant relationship between PTC, TA, ROAA and board meeting. $C A R$ and $N P L$ are not statistically significant relationship between board meetings.

This study wanted to examine whether the difference in performance of the banks in year 2007-2008 is statistically different from that of Year 2011-2012, the $t$ test is used to set the hypothesis. The results showed $P T C$ and ROAA are no statistically significant difference. $C A R, A S$ and $N P L$ are statistically significant difference.

And this study showed correlation coefficients between the dependent and independent variables.

The results showed that the corporate governance is positive direction to $C A R, P T C, T A, N P L$ and $R O A A$. Another testing of board size is indicated have negative direction to $C A R, T A$ and $N P L$. Finally, it showed that board meeting is negative direction to CAR and NPL.

Apart from the financial, risk, liquidity management and corporate governance will effect bank's operations. It still has other factors such as macro economic environment. The growth rate of an economy is another key indicator to measure economy. Growth of GDP is a significant factor affecting banking security. Bank loan quality deterioration when the business cycle is in a downward trend. A higher growth rate can show a more robust economy. In order to avoid distortion of short-term economic upturn or downturn in the form of at least three-year period used to measure the average change in GDP. Thus if it wants to avoiding the impact of inflation or deflation, real GDP should be used.

In order to maintain banks have good financial performance and operation; it should not have a qualified audit opinion. It is because banks are highly regulated entities and have duty to provide true and fair annual report information to regulators. It suggested conduct further studies in the future, researchers can take into consideration other industries and using others financial ratio variables to do testing.

\section{References}

Pablo de Andres, \& Eleuterio Vallelado. (2008). Corporate governance in banking: The role 
of the board of directors. Journal of Banking \& Finance, 32, 2570-2580.

Abdullah S. N. (2004). Board composition, CEO duality and performance among Malaysian listed companies, Journal of Finance, 32, 362-378.

Akhigbe, A., \& AD Martin. (2006). Valuation Impact of Sabanes-Oxley: Evidence from Disclosure and Governance within the Financial Services Industry. Journal of Banking and Finance, 30, 989-1006. http://dx.doi.org/10.1016/j.jbankfin.2005.06.002

Akkizidis, I. and Khandelwal, S. K. (2008). Financial Risk Management for Islamic Banking and Finance, Palgrave Macmillan, First Ed.

Bass, B. M. (1990). From transactional to transformational leadership: Learning to share the vision. Organizational Dynamics, 19-31. http://dx.doi.org/10.1016/0090-2616(90)90061-S

Coulton J. J., \& Taylor S. L. (2004). Directors Duties and Corporate Governance: Have We Gone Too Far? Australian Accounting Review, 14, 17-24. http://dx.doi.org/10.1111/j.1835-2561.2004.tb00279.x

Crutchley, C. E., \& Hansen, R. S. (1989). A Test of the Agency Theory of Managerial Ownership, Corporate Leverage, and Corporate Dividends. Journal of Financial Management, 36-46.

Dietrich, A., \& G. Wanzenried. (2011). Determinants of bank profitability before and during the crisis: evidence from Switzerland. Journal of International Financial Markets, Institutions and Money, 21, 307-327.

Dietrich. G. (1996). Efficiency measurement of the Greek commercial banks with the use of financial ratios: a data envelope analysis approach. Management Accounting Research, 15(2), 201-224.

Elizabeth, D., \& Elliot, G. (2004). Efficiency customer service and financial performance among australian financial institutions. International Journal of Bank Marketing, 22(5), 319-342. http://dx.doi.org/10.1108/02652320410549647

Gibbons, R. (1997). Incentives and Careers in Organizations, in D. Kreps and K.Wallis (eds.) Advances in Economic Theory and Econometrics, II (Cambridge, U.K.: Cambridge University Press).

Jensen, Michael C., \& Zimmerman, Jerold L. (1985). Management compensation and the managerial labor market. Journal of Accounting and Economics, 7(1-3), 3-9. http://dx.doi.org/10.1016/0165-4101(85)90025-4

Kim,P. Kwee., \& Rasiah,Devinaga. (2010). Relationship between Corporate Governance and Bank Performance in Malaysia during the Pre and Post Asian Financial Crisis European. Journal of Economics, Finance and Administrative Sciences - Issue 21, 39-63.

Koasmidou, K. (2008). The determinants of banks' profits in Greece during the period of EU financial integration. Managerial Finance, 34(3), 146-159.

Kotter, J. P. (1990a). What leaders really do, Harvard Business Review, 68, 103-111. 
Lazear, E. (2000). Performance, Pay and Productivity, American Economic Review, 90(5), 1346-1361. http://dx.doi.org/10.1257/aer.90.5.1346

Mangel, R.., \& Singh, H. (1993). Ownership Structure, Board Relationships and CEO Compensation in Large US Corporations, Accounting and Business Research, 23, 339-350 http://dx.doi.org/10.1080/00014788.1993.9729902

Monks, R. A. G. (2005). Corporate Governance-USA- Fall 2004 Reform-The Wrong Way and the Right Way. Corporate Governance, 13(2), 108-113. http://dx.doi.org/10.1111/j.1467-8683.2005.00409.x

Molyneux, P., \& Seth, R. (1998). Foreign banks, profits and commercial credit extension in the United States. Applied Financial Economics, 8, 533-539.

Murphy, K. J. (1999). Executive Compensation, Journal of Finance, 40, 339-350.

Novikova. (2004). The Impact of Internal Corporate Governance System on Firms Innovative Activities. Research design to be presented at the DRUID Academy's Winter Conference on Innovation, Growth and Industrial Dynamics Aalborg, Denmark.

Oberholzer, M., \& Van der Westhuizen, G. (2004). An empirical study on measuring efficiency and profitability of bank regions. Meditari Accounting Research, 12(1), 165-178. http://dx.doi.org/10.1108/10222529200400009

Pilloff, S. J., \& Rhoades, S. A. (2002). Structure and Profitability in Banking markets. Review of Industrial Organization, 20, 81-98. http://dx.doi.org/10.1023/A:1013362913973

Pi, L.., \& S.G. Timme. (1993). Corporate control and bank efficiency. Journal of Banking and Finance, 17, 515-530. http://dx.doi.org/10.1016/0378-4266(93)90050-N

Reese, William Jr., \& Weisbach, Michael S. (2002). Protection of minority shareholder interests, cross-listings in the United States, and subsequent equity offerings. Journal of Financial Economics, $\quad$ Elsevier, $\quad 66(1), \quad 65-104$. http://dx.doi.org/10.1016/S0304-405X(02)00151-4

Samad, A. (2004). Bahrain Commercial Bank's Performance during 1994-2001. Credit and Financial Management Review, 10(1), 33-40.

Seiford L. M., \& J. Zhu. (1999). Profitability and Marketability of the Top 55 US Commercial Banks. Management Science, 45(9), 1270-1288. http://dx.doi.org/10.1287/mnsc.45.9.1270

Shleifer A., Vishny R. (1997). A survey of corporate governance. Journal of Financial, 52, 737-775. http://dx.doi.org/10.1111/j.1540-6261.1997.tb04820.x

Spathis, C., Koasmidou, K., \& Doumpos, M. (2002). Assessing Profitability Factors in the Greek Banking System: Amulticriteria methodology. International Transactions in Operational Research, 517-530. http://dx.doi.org/10.1111/1475-3995.00371

Sun, Jerry \& Cahan, Steven F., \& Emanuel, David. (2009). Compensation committee governance quality, chief executive officer stock option grants, and future firm performance. 
Journal of Banking

http://dx.doi.org/10.1016/j.jbankfin.2009.02.015

Vroom, V. H. (1964). Work and motivation, New York: Wiley

William Q. Judge, Naoumova I., \& Koutzevol N. (2003). Corporate governance and firm performance in Russia: an empirical study. Journal of World Business, 38, 385-396. http://dx.doi.org/10.1016/j.jwb.2003.08.023

Yermack. (1996). Higher market valuation of companies with a small board of directors. Journal of Financial Economics, 40(2), 185-211.

\section{Copyright Disclaimer}

Copyright for this article is retained by the author(s), with first publication rights granted to the journal.

This is an open-access article distributed under the terms and conditions of the Creative Commons Attribution license (http://creativecommons.org/licenses/by/3.0/). 